\title{
Foreword to the 1995 Printing
}

\author{
Roy W. McDiarmid
}

$\mathrm{I}_{\mathrm{n}}$

1933, Comstock Publishing Company issued Anna Allen Wright and Albert Hazen Wright's Handbook of Frogs and Toads: The Frogs and Toads of the United States and Canada. The first of three editions, it was also the inaugural volume in the popular Comstock series, Handbooks of American Natural History. The first edition, 23I pages long, was published in a small format with a flexible cover. It began with a general introduction to frog natural history in the format of a species account, which was followed by keys to adults of species within each family of North American frogs. Next came the heart of the book, the species accounts. Most species accounts in the first edition were two pages long and followed the outline of the General Account. Included were comments on common and scientific names, the range and habitat of the species, its size, general appearance and distinctive structures, a description of its voice, and pertinent field notes from the Wrights' own observations as well as from colleagues and the literature. The accounts also detailed aspects of the species' breeding biology, including descriptions of eggs, tadpoles, development, and metamorphosis.

Typically, each account included a plate with three to nine photographs of live adults and sometimes of eggs and larvae. The Wrights had extensive field experience with the amphibians and reptiles of North America and took more than 12,000 photographs of these organisms (Adler, 1989). They placed considerable value on photographs of living specimens and in this regard were likely influenced by The Frog Book (Dickerson, 1907), another highly successful and well-illustrated book on frogs and toals of North America. Most photographs in the Handbook of Frogs and Toads were taken by the Wrights and newly published; some seemingly were the first published for the species. Several photographs had appeared in earlier works (e.g., A. H. Wright, 1914, 1932), and a few species (e.g., Rana tarahumarae) were represented by photographs of preserved specimens. The accounts of some species (e.g., Leptodactylus albilabris and Eleutherodactylus augusti) were illustrated with drawings from the literature; others, including that for Acris crepitans, lacked photographs altogether.

A second edition of the book, with the same title and order of authors, appeared nine years later. A hardcover volume in a slightly larger format, it had expanded to 286 pages and followed much the same style and organization of the first edition. Accounts and photographs of a few species (e.g., Acris crepitans) and subspecies (e.g., Bufo boreas nelsoni, Pseudacris nigrita verrucosa) not recognized or illustrated in the first edition were added, as were photographs of 
live individuals of species previously shown only as preserved specimens (e.g., Rana tarahumarae). The Notes section of some accounts contained information and observations made after the first edition appeared, and most accounts reflected an updated nomenclature.

The third edition was published in 1949. Retitled Handbook of Frogs and Toads of the United States and Canada, with Albert Hazen Wright listed as first author and Anna Allen Wright as second, the third edition was larger, considerably longer (640 pages), and hardbound. It went through several printings and is reprinted here. The General Account contained several new and expanded sections: a commentary on Anuran classification (some of these comments are as appropriate today as they were in 1949); a list of 29 species and subspecies that the Wrights thought needed more study (several still do!); a more detailed habitat section, which included maps of life zones and rainfall; a separate section on coloration; and a discussion of secondary sexual traits, such as vocal sac morphology, throat color, and tympanum size, with a key to species based on these characteristics. Although sexual characters are occasionally used as secondary traits in keys to adult frogs, few authors have tried the novel approach taken by the Wrights. Other new topics in the General Account were reviews of the timing and periodicity of breeding, egg-clutch characteristics and egg-laying processes, and egg morphology; 65 illustrations of eggs were included, as was an II-page synoptic key to eggs.

Another advance over the previous editions, and an important contribution to the field of amphibian biology, was the expanded section on tadpoles. Two plates of tadpole photographs, depicting 2I species of frogs, were added, along with three plates of drawings of oral discs showing the mouthparts of 28 species. The photographs had been published previously in Life-Histories of the Frogs of Okefinokee Swamp, Georgia (A. H. Wright, 1932), ' and some had appeared in even earlier publications (A. H. Wright, 1920, 1929). The drawings were the work of Anna Wright; Plates XII and XIV were reprinted from the Okefenokee volume, and Plate XIII was composed of drawings from Plates I and V of the 1929 synopsis. To this day, the photographs, mouthpart drawings, and portions of the descriptions are the best sources of data on the tadpoles of several species. An expanded key to tadpoles, originally published by Albert Wright in 1929, was included. It remained the only comprehensive key to these wonderful and interesting organisms until Ron Altig published his work in I970.

The species accounts were much longer than those in the previous editions and now made up nearly 75 percent of the volume. Included were maps of

\footnotetext{
${ }^{1}$ Kraig Adler (1989:75) has indicated that the spelling "Okefinokee" in the title was in error. That spelling was commonly accepted in the late i8oos, however, and frequently used at the time Wright wrote his book. Early in the twentieth century, the U.S. Geographical Board decreed that the spelling should be "Okefenokee," and that is the spelling used today.
} 
each species' distribution, more comprehensive color descriptions, and greatly lengthened natural history notes. Additional information on tadpole size and a section called "Authorities' Corner" completed the increased coverage in the third edition. The Authorities' Corner offered salient references and, in some cases, extensive quotes from the literature.

Species and subspecies new to the third edition (e.g., Bufo exsul) and some of those not illustrated in previous editions (e.g., Scaphiopus hammondii intermontanus, S. holbrooki hurterii, Bufo insidior, Rana onca) now had accounts complete with photographs. Illustrations of the remaining species, with a few exceptions (e.g., Hyla arenicolor), were not revised, although additional photographs supplemented some accounts (e.g., Rana areolata, $R$. pipiens). The account of Leptodactylus labialis included the same drawings together with eight new photographs of preserved specimens; Eleutherodactylus augusti, however, was still illustrated only with drawings from the literature. Arizona frogs of the latter species are rarely encountered, and I know of only one published photograph of an individual from that population (Bezy et al., 1966).

Accounts of some extralimital species (e.g., Rana forreri, $R$. montezumae, $R$. pustulosa from Mexico) were illustrated (see Plates CXIII and CXIV), yet a few species (e.g., Syrrhophus gaigeae, Rana sevosa, Microhyla areolata) had no illustrations. The latter three species are difficult to collect, which may account for the absence of photographs, but other forms, for which photographs of living specimens apparently were lacking, were illustrated with drawings from the literature or photographs of preserved material. Why the Wrights did not include drawings of those three species remains a mystery. Perhaps they were less sure of the validity of those forms and therefore not as inclined to illustrate the accounts with photographs of preserved specimens. The inclusion of detailed comparative measurements in the account for Syrrhophus gaigeae and the comments under the Authorities' Corner for Microhyla areolata seem to support this notion.

Although the bulk of the Wrights' scientific contributions were in the fields of ecology and natural history, especially of frogs and snakes, they did devote considerable space in their writings to resolving perplexing systematics problems. In the third edition of the frog handbook, for example, they allotted 23 pages, Io plates, and 2 maps to a presentation of the Rana pipiens complex. Their efforts are perhaps best captured in the following statement, found on page 500: "We present this rambling treatment to provoke thorough studystudy of all the collections plus travel experience with these very forms, their eggs, tadpoles, and life histories. We are past appraisals of alcoholic specimens alone." It seems likely that some of their discussion and comments about the pipiens complex influenced later herpetologists to seek new approaches to solving this difficult systematics problem. The discovery more than a decade later that distinct morphotypes occurred sympatrically without hybridizing and that sympatric forms frequently partitioned breeding sites temporally was certainly 
an important achievement, one based on the Wrights' recommendations for further study. Since then, the geographic analyses of calls of various forms from critical areas and the use of molecular techniques to examine the degree of relatedness among morphotypes have contributed extensively to our knowledge of the group. Today, the pipiens complex is thought to include approximately 27 species, of which at least ro have been reported from the United States (Hillis, 1988). This understanding of the group is a significant departure from the systematics picture presented by the Wrights in 1949. Even so, their contributions to defining and resolving this problem are notable. And the picture continues to change: James Platz (1993) used morphometric and call data to define a new species, Rana subaquavocalis, from southern Arizona; in the same paper he presented data that suggest other forms remain to be discovered.

Although the Wrights' discussions of some groups (e.g., Rana pipiens complex) show understanding and insight, presentations in other accounts are puzzling. In the first and second editions, for example, the Wrights stated that the form Pseudacris occidentalis was probably a synonym of Hyla regilla (a conclusion with which I am inclined to agree if the type locality, originally given as San Francisco, is correct; also see Smith [1966] contra Schmidt [1953] and Duellman [1977]). In the third edition (262), they began the account with the statement "This frog probably does not exist," but then devoted more than two pages to its discussion. Clearly, resolution of species problems in Pseudacris were and continue to be difficult, but I believe that the Wrights were reluctant to follow their instincts because many literature reports of $P$. occidentalis, as well as specimens in collections, were attributed to friends (262). Support for this view can be found elsewhere. In the account for Microbyla areolata the Wrights commented that they never believed very strongly in the form but retained it because of attachment for its author, J. K. Strecker. They also thought that "this volume should be conservative and suggestive" (571). One could argue that inclusion of all possible names was conservative, but other actions, such as describing a new species, were not and seem out of place. For example, the type description of Pseudacris streckeri in the key and species account in the first edition (1933:25, 102-103, Plate XXXV) has problems with the designation of type specimens and type locality (Smith, 1966). Similar concerns about the status of type specimens of Rana heckscheri, the only other frog species described by A. H. Wright (1924), were raised by Sanders (1984). And a careful reading of the figure captions for $R$. heckscheri (Wright, 1924; Wright and Wright, 1933) reveals other discrepancies with specimens and collection dates. Fortunately, these sorts of problems were few and relatively minor.

My only contact with the Wrights has been through their books and papers, and the talks I have had with colleagues who knew them at Cornell University. Their scientific legacy lies in the areas of ecology and life history studies and in the many students they influenced during their tenure at Cornell (Adler, 1989). Through their publications, especially the handbook series, the Wrights had an 
immense influence on the study of frog natural history in this country. Their publications on the life histories of frogs in Ithaca, New York, and the Okefenokee Swamp of Georgia are classics in every sense, and no works comparable to those volumes on North American species have been published since. I would guess that no North American scientist in the first half of this century had a more profound effect on students interested in the ecological aspects of the natural history of frogs than Anna Allen and Albert Hazen Wright.

Although I grew up in California and "cut my teeth" on the informative and well-written volumes of Robert C. Stebbins (I95I, 1954) on western species, librarians in the local public library in Whittier must have wondered about the kid who renewed the Wrights' Handbook of Frogs and Toads week after week after week. It wasn't until many years later, when I was trying to learn the breeding habits of the confusing array of species of Rana in the Southeast and to identify tadpoles from Florida, that I came to appreciate the importance of the Wrights' contributions, especially their summaries on eggs, tadpoles, and breeding biology.

Those who have not previously read this volume may question the value of what appear to be unsynthesized and unedited notes and quotes under the Habitat, Breeding, and Journal Notes sections of species accounts. This style, also found in the two volumes on snakes, characterizes most of the writings of Albert Hazen Wright. The accounts represent the Wrights' summary of knowledge on the natural history of frogs and toads through the first half of this century, and in that sense, the volume provides a significant start for the next person who undertakes to write a book of this detail and coverage. The style also conveys the excitement and frustration of field work as the Wrights experienced it. Personally, I gained a fresh view of the kinds and extent of interactions among herpetologists during the period in which they wrote the three editions. Scientists seemed more cooperative and interactive than today, perhaps because the herpetological community was much smaller. Many people respected the Wrights and their work. Albert Hazen Wright was elected Eminent Ecologist by the Ecological Society of America in 1955, and the contributions of both were recognized by Edward H. Taylor, who named a species of tree frog, Hyla wrightorum, for them (Taylor, 1938).

As investigators continue to examine the nature of geographic variation of North American frogs and toads, especially in species with disjunct populations, and the degree of relatedness among species, our understanding of species' boundaries will change even more from that presented by the Wrights. Since publication of the third edition, several new species have been described (e.g., Bufo retiformis, Rana okaloosae), some have been recorded from the United States for the first time (e.g., Rhinophrynus dorsalis, Syrrhophus guttilatus), and others have been successfully introduced (e.g., Xenopus laevis, Eleutherodactylus coqui). During the same period, regional populations of Bufo 
boreas, Rana boylii, $R$. chiricabuensis, $R$. pretiosa, and several other species in western states have declined or disappeared from historical sites. Rana tarahumarae evidently has been extirpated from Arizona (populations still exist in Mexico), and $R$. fisheri apparently is extinct. (Such reports have raised considerable concern in the herpetological community and point to the need for more long-term ecological studies of individual species and for studies designed to identify the causes of reported declines.) Today, we better understand relationships among forms and place less emphasis on subspecific differences than did herpetologists in the Wrights' era, but much remains to be learned. Recent work using biochemical and karyological techniques suggests that several distinct species will likely be recognized within what are currently considered single species. Candidates for further investigation include some forms of $B u f o$, especially $B$. boreas, and certain species of Rana, including $R$ aurora, $R$. pretiosa, and $R$. sphenocephala. As advances occur, the need for a revision of this volume will become more manifest. In the meantime, I provide at the end of this Foreword a list of currently recognized species of North American frogs and toads as a supplement to the names used by the Wrights.

I learned a great deal about the Wrights during preparation of this essay, and I very much appreciate the opportunity provided me by Cornell University Press to share my views. I was struck in particular by the Wrights' dedication of this book to four American women-Mary Hewes Hinckley, Mary Cynthia Dickerson, Helen Dean King, and Helen Thompson Gaige--all of whom contributed notably to the study of frogs and toads. Having recently read several papers by Mary Hinckley written in the 188 os on the morphology and development of North American tadpoles, I concluded that had more tadpole workers followed her example and presented stylized illustrations of tadpole mouthparts, we would be further along in our quest to comprehend the variation and distribution of larval traits, and their value in discerning frog phylogeny. Mary Dickerson, a curator of herpetology at the American Museum of Natural History, influenced several prominent herpetologists early in their careers (see Adler, 1989). She is probably best known for her classic work, titled simply The Frog Book (Dickerson, 1907). Helen King wrote several interesting papers in the early I900s on development and sex determination in amphibians. If developmental biologists today were doing more along the lines of the experimental and comparative research done by Helen King, we would likely better understand the nature and evolution of larval traits of frogs. Lamentably, we are not training many comparative embryologists now. Helen Gaige, the last of the scientists named by the Wrights in their dedication, was curator of herpetology at the Museum of Zoology, University of Michigan. Kraig Adler (1989) provided a short biographical sketch of Gaige in his informative review of past herpetologists. She was heavily involved in the programs and activities of the American Society of Ichthyologists and Herpetologists, serving as an editor of its journal, Copeia, from 1930 to 1949. In recognition of her contributions, the 
membership in 1946 elected her honorary president for life. Gaige Awards, funded by her estate, are available to student members of the society in support of meritorious research projects. Her own research on the life history and description of the tadpole of the tailed frog Ascaphus truei was well known. In their introduction to the family Ascaphidae in this handbook, the Wrights wrote, "The first recognition of this form by Dr. Stejneger and the subsequent studies of it by Dr. Helen Thompson Gaige were two of the outstanding events in North American batrachology in the last forty-five years" (IO4). Her other research interests centered primarily on descriptions of new species of frogs from Central and South America.

Even though each of these women made important contributions to the study of amphibian life histories, that a book written in 1933 would be dedicated to four women herpetologists seems unusual. I can only wonder whether it would have been dedicated to any of these scientists if Anna Allen Wright had not been the first author of the first and second editions. It has been nearly impossible to ascertain the nature and quantity of Anna Allen Wright's contributions to her husband's career. She was prominently acknowledged in all his works that I reviewed, and I have the impression that she and Albert were constant companions in and out of science. Albert Hazen Wright received numerous accolades during his distinguished career, but I am unaware of any bestowed on Anna, even though she likely deserved many. Clearly, she played a major role in his career and was a true collaborator in many aspects of their joint research. The Wrights were the only couple that Adler included in his 1989 review of scientists who have influenced herpetology profoundly, and this in itself seems significant.

A comparison of the Preface to the first or second edition of this handbook (the two prefaces are much the same) with the Preface to the third edition reveals that the latter has been completely rewritten and updated. I suspect that the Preface of the third edition more reflects the views of Albert Hazen Wright, the senior author. A statement in the Preface to the first edition caught my eye: "The plates and script are meant to cultivate an interest in the lay mind and help the beginner in his or her quests." Although somewhat insignificant in itself, this statement convinces me that Anna was a major participant in the Wrights' work and that she likely served as an important role model for women scientists of her time. I am not suggesting that Albert Hazen Wright was not supportive of women in science, nor cognizant of the contributions that Anna made to his career. In fact, he frequently used "we" and "our" when referring to work, travel, and data, even in papers authored solely by him. Rather, it seems to me that, for many of us, our professional and personal lives are completely intertwined and that, in the case of couples, as is my perception of the Wrights, individual identities are often lost. It is unfortunate that women, particularly wives in two-career couples, often do not receive the credit they so frequently deserve. 
I view the Wrights' Dedication as a timely and deserved recognition of the considerable contributions made by four women herpetologists. Aspiring young herpetologists, especially those named Mary, Helen, or Anna, should be bolstered by the accomplishments of these women. To this list of celebrated female herpetologists, I would add Anna Allen Wright. I suspect that she made many more contributions than is indicated by her authorship.

In retrospect, I regret not having had the opportunity to swap herp stories with the Wrights. I know I would have enjoyed hearing of their extensive field experience with frogs, snakes, and the other interesting, exciting animals that were so much a part of their lives. They both made major contributions to herpetology, and the reprinting of this volume is a tribute to their efforts.

\section{REFERENCES}

Adler, K. 1989. Herpetologists of the past. 5-14I. In K. Adler, ed., Contributions to the History of Herpetology, Society for the Study of Amphibians and Reptiles, Contributions to Herpetology no. 5. Oxford, Ohio. 202 pp.

Altig, R. 1970. A key to the tadpoles of the continental United States and Canada. Herpetologica 26:180-207.

Bezy, R. L., W. C. Sherbrooke, and C. H. Lowe. 1966. The rediscovery of Eleutherodactylus augusti in Arizona. Herpetologica 22:221-225.

Dickerson, M. C. 1907. The Frog Book. Doubleday, New York. xvii + 253 pp.

Duellman, W. E. 1977. Liste der rezenten Amphibien und Reptilien. Hylidae, Centrolenidae, Pseudidae. Das Tierreich (95), Walter de Gruyter, Berlin. xix + 225 pp.

Hillis, D. M. 1988. Systematics of the Rana pipiens complex: Puzzle and paradigm. Ann. Rev. Ecol. Syst. 19:39-63.

Platz, J. E. 1993. Rana subaquavocalis, a remarkable new species of leopard frog (Rana pipiens complex) from southeastern Arizona that calls under water. J. Herpetol. 27:154162.

Sanders, A. E. 1984. Rana heckscheri. Cat. Amer. Amphib. Rept. 348.I-348.2.

Schmidt, K. P. 1953. A check list of North American amphibians and reptiles. Sixth ed. Amer. Soc. Ichthyol. Herpetol., Chicago. viii +280 pp.

Smith, P. W. 1966. Pseudacris streckeri. Cat. Amer. Amphib. Rept. 27.I-27.2.

Stebbins, R. C. 1951. Amphibians of Western North America. University of California Press, Berkeley. ix + 539 pp.

- 1954. Amphibians and Reptiles of Western North America. McGraw-Hill, New York. $\mathrm{xxii}+536 \mathrm{pp}$.

Taylor, E. H. 1938. Frogs of the Hyla eximia group in Mexico, with descriptions of two new species. Univ. Kansas Sci. Bull. 25(19):421-445.

Wright, A. A., and A. H. Wright. 1933. Handbook of Frogs and Toads-The Frogs and Toads of the United States and Canada. Handbooks of American Natural History, Vol. I. Comstock Publishing Co., Ithaca, N.Y. xi +231 pp.

- 1942. Handbook of Frogs and Toads-The Frogs and Toads of the United States and Canada. Second ed. Handbooks of American Natural History, Vol. I, Comstock Publishing Co., Ithaca, N.Y. xi +286 pp. 
Wright, A. H. 1914. North American Anura-Life-Histories of the Anura of Ithaca, New York. Carnegie Institution of Washington Publ. no. 197. vii +98 pp.

- 1920. Frogs: Their natural history and utilization. U.S. Bur. Fisheries Document no. 888, pp. I-44.

- 1924. A new bullfrog (Rana heckscheri) from Georgia and Florida. Proc. Biol. Soc. Washington 37:I4I-I52, plates XI-XII.

- 1929. Synopsis and description of North American tadpoles. Proc. U.S. Natl. Mus. no. 2756, pp. I-70, plates I-IX. .

- 1932. Life-Histories of the Frogs of Okefinokee Swamp, Georgia. North American Salientia (Anura) no. 2. Macmillan Co., New York. xv +497 pp.

Currently recognized species of frogs and toads of the United States and Canada as compared with the species and subspecies included in the third edition of Wright and Wright's Handbook of Frogs and Toads

Current use

Ascaphus truei

Xenopus laevis

Rhinophrynus doralis

Scaphiopus couchii

Scaphiopus holbrookii

Spea bombifrons

Spea hammondii

Spea intermontana

Spea multiplicata

Eleutherodactylus augusti

Eleutherodactylus coqui

Eleutherodactylus planirostris
Use in Wright and Wright

\section{Ascaphidae}

Ascaphus truei

\section{Pipidae}

\section{Rhinophrynidae}

\section{Pelobatidae}

Scaphiopus couchii

Scaphiopus holbrookii holbrookii

Scaphiopus holbrookii albus

Scaphiopus holbrookii hurterii

Scaphiopus hammondii bombifrons

Scaphiopus hammondii hammondii (part)

Scaphiopus hammondii intermontana

Scaphiopus hammondii hammondii

(part)

\section{Leptodactylidae}

Eleutherodactylus augusti

Eleutherodactylus latrans

Eleutherodactylus ricordii planirostris 


\begin{tabular}{ll} 
Current use & Use in Wright and Wright \\
\hline Leptodactylus labialis & Leptodactylus labialis \\
Syrrhophus cystignathoides & Syrrhophus campi \\
Syrrhophus guttilatus & \\
Syrrhophus marnockii & Syrrhophus marnockii \\
& Syrrhophus gaigeae
\end{tabular}

Bufo alvarius
Bufo americanus

Bufo boreas

Bufo californicus

Bufo canorus

Bufo cognatus

Bufo debilis

Bufo exsul

Bufo hemiophrys

Bufo houstonensis

Bufo marinus

Bufo microscaphus

Bufo nelsoni

Bufo punctatus

Bufo quercicus

Bufo retiformis

Bufo speciosus

Bufo terrestris

Bufo valliceps

Bufo woodhousii

Acris crepitans

Acris gryllus

Hyla andersonii

Hyla arenicolor

Hyla avivoca

Hyla chrysoscelis

Hyla cinerea

\section{Bufonidae}

Bufo alvarius

Bufo americanus americanus

Bufo americanus copei

Bufo boreas boreas

Bufo boreas halophilus

Bufo californicus

Bufo canorus

Bufo cognatus

Bufo debilis

Bufo insidior

Bufo exsul

Bufo hemiophrys

Bufo marinus

Bufo compactilis (part)

Bufo boreas nelsoni

Bufo punctatus

Bufo quercicus

Bufo compactilis (part)

Bufo terrestris

Bufo valliceps

Bufo woodhousii woodhousii

Bufo woodhousii fowleri

\section{Hylidae}

Acris gryllus crepitans

Acris gryllus gryllus

Hyla andersonii

Hyla arenicolor (part)

Hyla avivoca

Hyla versicolor chrysoscelis

Hyla cinerea cinerea 
Current use

Hyla femoralis

Hyla gratiosa

Hyla squirella

Hyla versicolor

Hyla wrightorum

Osteopilus septentrionalis

Pseudacris brachyphona

Pseudacris brimleyi

Pseudacris cadaverina

Pseudacris clarkii

Pseudacris crucifer

Pseudacris nigrita

Pseudacris ocularis

Pseudacris ornata

Pseudacris regilla

Pseudacris streckeri

Pseudacris triseriata

Pternohyla fodiens

Smilisca baudinii

Gastrophryne carolinensis

Gastrophryne olivacea

Hypopachus variolosus

Rana areolata

Rana aurora

Rana berlandieri
Use in Wright and Wright

Hyla cinerea evittata

Hyla femoralis

Hyla gratiosa

Hyla squirella

Hyla versicolor versicolor

Hyla versicolor phaeocrypta

Hyla wrightorum

Hyla septentrionalis

Pseudacris brachyphona

Pseudacris brimleyi

Hyla arenicolor (part)

Pseudacris nigrita clarkii

Hyla crucifer crucifer

Hyla crucifer bartramiana

Pseudacris nigrita nigrita

Pseudacris nigrita feriarum

Pseudacris nigrita septentrionalis

Pseudacris nigrita verrucosa

Pseudacris ocularis

Pseudacris ornata

Hyla regilla

Pseudacris occidentalis

Pseudacris streckeri

Pseudacris nigrita triseriata

Hyla baudinii

\section{Microhylidae}

Microhyla carolinensis

Microhyla olivacea

Microhyla areolata

Microhyla mazatlanensis

Hypopachus cuneus

\section{Ranidae}

Rana areolata areolata

Rana areolata circulosa

Rana aurora aurora

Rana aurora draytonii

Rana pipiens berlandieri 
Current use

Rana blairi

Rana boylii

Rana capito

Rana cascadae

Rana catesbeiana

Rana chiricahuensis

Rana clamitans

Rana fisheri

Rana grylio

Rana heckscheri

Rana muscosa

Rana okaloosae

Rana onca

Rana palustris

Rana pipiens

Rana pretiosa

Rana septentrionalis

Rana sphenocephala

Rana subaquavocalis

Rana sylvatica

Rana tarahumarae

Rana virgatipes

Rana yavapaiensis
Use in Wright and Wright

Rana pipiens complex (part)

Rana boylii boylii

Rana boylii sierrae

Rana capito

Rana sevosa

Rana cascadae

Rana catesbeiana

Rana pipiens complex (part)

Rana clamitans

Rana fisheri

Rana grylio

Rana heckscheri

Rana boylii muscosa

Rana onca

Rana palustris

Rana pipiens complex

Rana pipiens brachycephala

Rana pipiens pipiens

Rana pipiens burnsi

Rana pipiens kandiyohi

Rana pretiosa pretiosa

Rana pretiosa luteiventris

Rana septentrionalis

Rana pipiens sphenocephala

Rana sylvatica sylvatica

Rana sylvatica cantabrigensis

Rana tarahumarae

Rana virgatipes

Rana pipiens complex (part) 